\title{
THE EFFECT OF BLADDER PAIN SYNDROME/INTERSTITIAL CYSTITIS ON PARTNER SEXUAL FUNCTIONS
}

\author{
AĞRILI MESANE SENDROMU/INTERSTISYEL SISTITIN PARTNER SEXÜEL \\ FONKSIYONLARINA ETKISI
}

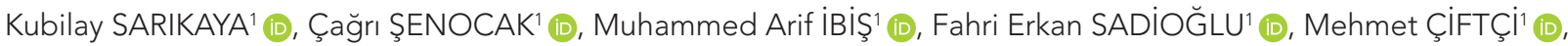 \\ Ömer Faruk BOZKURT'1 iD
}

${ }^{1}$ Keçiören Training and Research Hospital, Department of Urology, Ankara, Turkey

ORCID IDs of the authors: K.S. 0000-0003-1734-2392; Ç.Ş. 0000-0001-5696-6320; M.A.I. 0000-0001-8581-2101;

F.E.S. 0000-0002-4454-0274; M.Ç. 0000-0003-4178-2865; Ö.F.B. 0000-0002-6684-5431

Cite this article as: Sarikaya K, Senocak C, Ibis MA, Sadioglu FE, Ciftci M, Bozkurt OF. The effect of bladder pain syndrome/interstitial cystitis on partner sexual functions. J Ist Faculty Med 2022;85(1):110-6. doi: 10.26650/IUITFD.948137

\section{ABSTRACT}

Objective: Bladder pain syndrome/Interstitial cystitis (BPS/IC) negatively affects both women's social life and sexual functions. The study researched if this situation can negatively affect the sexual functions of the male partners of these women.

Materials and Methods: The husbands of fifty female patients, who were treated for BPS/IC in our clinic, were contacted by telephone. The international index of erectile function-5 (IIEF5), premature ejaculation diagnostic tool (PEDT), orgasmic function, sexual desire, sexual intercourse satisfaction and total satisfaction scores were used for the survey (Group 1). The same questionnaire was also used with fifty men whose wives did not have IC/BPS but who had applied to the urology outpatient clinic (Group 2). The scores of the participants were recorded and then the groups were compared.

Results: The median IIEF-5 score was 23 (22-24) in both groups $(p=0.899)$. Both groups had a median orgasmic score of $8(7-9)$ $(p=0.980)$. While the Median PEDT score was $7.00(4.00-12.25)$ in Group 1, it was 4.50 (3.00-6.00) in Group 2 ( $p=0.002)$. The men in Group 2 were significantly more advantageous than Group 1 in terms of sexual desire, sexual intercourse satisfaction and total satisfaction scores, $(p=0.003, p=0.0001$ and $p=0.003$, respectively).

Conclusion: Although BPS/IC does not have a significant effect on the IIEF- 5 score of the husbands of women, it negatively affects the scores of sexual desire, sexual intercourse satisfaction, total satisfaction and premature ejaculation.

Keywords: Painful bladder, interstitial cystitis, partner sexual dysfunction

\section{ÖZET}

Amaç: Ağrılı mesane sendromu/Interstisyel sistit (BPS/IC) kadınların gerek sosyal hayatlarına gerekse de seksüel fonksiyonlarına negatif etki etmektedir. Çalışmamızda bu durumun kadınların eşlerinin seksüel fonksiyonlarına etkisi olup olmadığını göstermeyi amaçladık.

Gereç ve Yöntem: Kliniğimizde BPS/IC nedeniyle tedavi gören 50 kadın hastanın eşlerine telefonla ulaşılarak hastaneye çağıılıp uluslararası erektil fonksiyon-5 (IIEF-5), prematür ejekülasyon (PEDT), orgazmik fonksiyon, seksüel istek, cinsel ilişki memnuniyet ve total memnuniyet skorları sorgulanmıştır (Grup 1). Aynı sorgulama eşinde interstisyel sistit olmayan ve üroloji polikliniğine başvuran diğer 50 erkek üzerinde de yapılmıştır (Grup 2). Katılımcıların skorları kayıt altına alınarak gruplar karşılaştırılmıştır.

Bulgular: Median IIEF-5 skoru her iki grupta da 23 (22-24) bulunmuştur $(p=0,899)$. Her iki grubun median orgazmik skorunun 8 (7-9) olduğu görülmüştür $(p=0,980)$. Median PEDT skoru Grup 1'de 7,00 (4,00-12,25) iken Grup 2' de 4,50 (3,00-6,00) bulunmuştur $(p=0,002)$. Seksüel istek, cinsel ilişki memnuniyet ve total memnuniyet skorları bakımından da Grup 2'deki erkeklerin Grup 1'den anlamlı olarak avantajıı olduğu görülmüştür (sırasıyla, $p=0,003, p=0,0001$ ve $p=0,003$ ).

Sonuç: IC/BPS, kadınların eşlerinin IIEF-5 skoru üstünde anlamI etki yapmasa da seksüel istek, cinsel ilişki memnuniyet, total memnuniyet ve prematür ejekülasyon skorlarını olumsuz yönde etkilemektedir.

Anahtar Kelimeler: Ağrılı mesane, interstisyel sistit, partner seksüel disfonksiyonu

Corresponding author/iletişim kurulacak yazar: drkubilay.sarikaya76@outlook.com

Submitted/Başvuru: 04.06.2021 • Revision Requested/Revizyon Talebi: 30.08.2021 •

Last Revision Received/Son Revizyon: 06.09.2021 • Accepted/Kabul: 07.09.2021 • Published Online/Online Yayın: 05.01.2022 


\section{INTRODUCTION}

Bladder pain syndrome/Interstitial cystitis (BPS/IC) is defined as a "persistent or recurrent chronic pelvic pain, pressure or discomfort perceived to be related to the urinary bladder accompanied by at least one other urinary symptom such as an urgent need to void or urinary frequency " by the International Continence Society (1). Recent studies indicate that the prevalence of BPS/IC in women is approximately $2.7-6.5 \%$ (2). Several treatment options of BPS/IC have been defined such as behavioral therapies, oral pharmacological agents, intravesical treatments, hydrodistension and various surgical procedures (3). This uncomfortable situation negatively affects the quality of life of women by causing significant problems both in their social activities and work life (4). One of the most important problems caused by BPS/IC in women is its negative effect on sexual functions $(5,6)$. Chronic pain in the suprapubic area causes lack of interest to engage in a sexual relationship in women and this results in sexual avoidance, orgasm problems, and depression, which negatively affects the quality of life in the future (7). The negative effect of "sexual avoidance behavior" in women on the sexual functions of male partners or husbands of women has been shown in numerous studies in the psycho-sexual field (8). Although the negative effects of BPS/IC on the sexual functions of women were evaluated in studies, the literature data on how this situation affects the sexual functions of the male partner or husbands of women is quite limited. Therefore, this study will examine the sexual functions of husbands of women with BPS/IC and indicate to what extent their husbands' sexual functions were affected by this situation.

\section{MATERIALS AND METHODS}

After obtaining approval from the ethics committee of Keçiören Training and Research Hospital (Date:23.03.2021, No: 2012-KAEK-15/2274), a prospective cohort study was designed which included a total of one hundred sexually active male participants. To determine their sexual functions, the husbands of fifty female patients who were treated for BPS/IC for at least a year or more and followed-up in our clinic, were invited by telephone to participate in the study group (Group 1). In the histories of women with BPS/IC, pain or pressure sensations in the pelvic area, daily frequency or urgency symptoms, increased pain during bladder filling, and bladder pain symptoms that did not improve with antibiotic treatment were studied in detail. The exclusion criteria from this study were the presence of bladder cancer, presence of spinal cord damage or neurological disease that may cause bladder dysfunction (Parkinson's disease, multiple sclerosis, spina bifida), presence of genital herpes, presence of gynecological malignancy or radiation therapy to pelvic area. After evaluating the bladder diary results of the patients, urine analysis, urine culture, blood urea and creatinine values were examined. The presence of glomerulation or Hunner's ulcer was eval- uated by performing cystoscopic imaging in all patients with BPS/IC, and punch biopsy was taken when necessary. Cystoscopy findings and biopsy results of the patients were classified using the European Society for the Study of Interstitial Cystitis (ESSIC) scale (9). The O'Leary scale, which was validated in Turkish version, was used to determine the symptom index of women with BPS/IC (10). This scale includes the interstitial cystitis symptom index (ICSI) and the interstitial cystitis problem index (ICPI). ICSI consists of a total of four questions that look at the frequency of urination during the daytime and at night, sudden urgency, nocturia , pelvic pain, and was evaluated from 0-20 points. The ICPI examines how many problems the symptoms questioned in ICSI cause in daily life and an evaluation was made in the range of 0-16 points. Fifty sexually active men from a similar age range and who applied to the urology outpatient clinic were included in the study and became a control group (Group 2). All patients in the groups were informed about the study and a written consent form was obtained. Sexual functions of men in Group 1 before BPS/IC symptoms in their wives and at least one year after the onset of BPS/IC symptoms were examined in detail. The previous sexual status of the men in Group 1 was made at the time of the diagnosis of BPS/IC by questioning the status of their partner before the onset of symptoms. Patients with co-morbidities that may adversely affect sexual functions such as hypertension, uncontrolled diabetes mellitus, dyslipidemia, alcoholism, and obesity were not included in the study. Another exclusion was the presence of erectile dysfunction secondary to any organic pathology previously revealed by penile Doppler Ultrasonography. In addition, the patients who had previous prostate surgery (transurethral prostatectomy, open prostatectomy, or radical prostatectomy), penile curvature surgery due to Peyronie's disease or congenital penile curvature, hypospadias or open urethroplasty were excluded from the study.

The participants included in the study were evaluated with the international index of erectile function form (IIEF) and the premature ejaculation diagnostic tool (PEDT), which were both validated in Turkish $(11,12)$. The first five questions (IIEF-5) in the IIEF form on erectile function were used for the survey study. Each of the questions in this area scored in the 0 to 5 point range. According to the scoring system, 5-7 points are considered severe erectile dysfunction (ED), 8-11 points as moderate ED, 12-16 points as mild-moderate ED, 17-21 points as mild ED, 22-25 points as no ED. The $9^{\text {th }}$ and $10^{\text {th }}$ questions of the IIEF form are related to orgasmic function and each of the questions is scored in the 0 to 5 point range and consists of a total of 0 to 10 points. The $11^{\text {th }}$ and $12^{\text {th }}$ questions of the IIEF form are about sexual desire and the questions are scored between 1 to 5 points and consist of 2 to 10 points in total. The $6^{\text {th }}, 7^{\text {th }}$ and $8^{\text {th }}$ questions of the IIEF form determine sexual intercourse satisfaction, each of the questions is scored between 0 to 5 points and consists of 0 to 15 points in total. The $13^{\text {th }}$ and $14^{\text {th }}$ questions 
of the IIEF questionnaire determine the overall satisfaction score, and each of the questions is scored between 1 to 5 and consists of a total of 2 to 10 points. The PEDT form used in this study to determine the male premature ejaculation parameters consists of five questions with a total score in the range of 0 to 22 points. According to this scoring system, 0-8 points indicate the presence of low probability PE, 9-10 points indicate the possible presence of $\mathrm{PE}$, and 11-22 points indicate the presence of $\mathrm{PE}$.

The sexual function of the participants in Group 1 before the development of BPS/IC symptoms in their wives (Before BPS/IC-Group 1) and at least one year after the symptoms developed (After BPS/IC-Group 1) were compared. In addition, the pre-symptom and post-symptom sexual function scores of the participants in Group 1 were compared with Group 2 separately.

\section{Statistical analysis}

The Kolmogorow-Smirnov test was used for testing the distribution of variables, while continuous variables were compared using the Mann-Whitney $U$ test and the Wilcoxon signed-rank test for univariate analyses. The median minimum, maximum, interquartile range, mean \pm standard deviation was used for defining variables. Data was analyzed with SPSS 25.0 (IBM Corp, Armonk, NY). software. Statistical significance was set at $p<0.05$.

\section{RESULTS}

The median age of Group 1 was 37.00 (28.75-46.00) years, and the median age of Group 2 was 34.00 (28.00-48.00) years $(p=0.759)$. While the median body mass index (BMI) of the men in Group 1 was $25.00(24.00-27.00) \mathrm{kg} / \mathrm{m}^{2}$, it was 26.00 (24.00-27.25) kg/m² in Group 2 ( $p=0.837)$. ICSI score of the wives of the participants in Group 1 was $13.14 \pm 3.12$ and the mean ICPI score was 11.10 \pm 2.35 . ESSIC groups of women with BPS/IC were determined according to cystoscopic imaging results (Table 1).

The men in Group 1 stated that they had sexual intercourse with their wives a median of four (2-5) times in a month, while the men in Group 2 stated that they had sexual intercourse with a median of eight (6-8) times in a month, and the median number of sexual intercourse of the participants in Group 2 was significantly higher compared to Group 1 ( $p=0.0001)$.

There was no significant difference in mean IIEF-5 and mean orgasmic function scores before BPS/IC and after BPS/IC in men in Group 1 (22.20 \pm 3.31 vs 22.34 \pm 3.15 , $p=0.968$ and $8.04 \pm 1.66$ vs $7.60 \pm 2.50, p=0.585$ respectively). While the mean PEDT score was $5.42 \pm 3.51$ before BPS/IC, it was $8.12 \pm 5.02$ after BPS/IC in Group 1 $(p=0.002)$. In terms of sexual desire, intercourse satisfaction, and overall satisfaction, it was determined that the men in Group 1 were significantly more advantageous in the before BPS/IC period compared to the after BPS/ $I C$ period ( $p=0.002, p=0.585$ and $p=0.002$ respectively) (Table 2). The median IIEF-5 score was 23 (9-25) in the before BPS/IC-Group 1, and it was 23 (8-25) in Group 2 $(p=0.750)$. While the median PEDT score was $4(2-17)$ in

Table 1: ESSIC groups and O'Leary scores of the women with BPS/IC in Group $1(n=50)$

\begin{tabular}{lc}
\hline ESSIC group & $\mathbf{n}(\%)$ \\
$1 \mathrm{X}$ & $3(6 \%)$ \\
$1 \mathrm{~A}$ & $8(16 \%)$ \\
$1 \mathrm{~B}$ & $2(4 \%)$ \\
$1 \mathrm{C}$ & $3(6 \%)$ \\
2A & $2(4 \%)$ \\
2B & $4(8 \%)$ \\
$2 \mathrm{C}$ & $13(26 \%)$ \\
$3 \mathrm{~A}$ & $3(6 \%)$ \\
$3 B$ & $5(10 \%)$ \\
$3 C$ & $7(14 \%)$ \\
ICSI score, mean \pm SD & $13.14 \pm 3.12$ \\
ICPI score, mean \pm SD & $11.10 \pm 2.35$ \\
\hline
\end{tabular}

ESSIC: European Society for the Study of Interstitial Cystitis, ICSI: interstitial cystitis symptom index, ICPI: interstitial cystitis problem index, SD: Standard deviation

Table 2: Comparison of sexual functions before and after BPS/IC in Group 1

\begin{tabular}{|c|c|c|c|}
\hline Scores & Before BPS/IC-Group 1 & After BPS/IC-Group 1 & $p$ value \\
\hline IIEF-5, Mean \pm SD & $22.20 \pm 3.31$ & $22.34 \pm 3.15$ & 0.968 \\
\hline PEDT, Mean \pm SD & $5.42 \pm 3.51$ & $8.12 \pm 5.02$ & 0.002 \\
\hline Orgasmic function, Mean \pm SD & $8.04 \pm 1.66$ & $7.60 \pm 2.50$ & 0.585 \\
\hline Sexual desire, Mean \pm SD & $7.96 \pm 1.67$ & $6.36 \pm 2.55$ & 0.002 \\
\hline Intercourse satisfaction, Mean \pm SD & $10.82 \pm 3.04$ & $8.32 \pm 3.41$ & 0.003 \\
\hline Overall satisfaction, Mean \pm SD & $8.98 \pm 11.68$ & $5.84 \pm 2.59$ & 0.002 \\
\hline
\end{tabular}

BPS/IC: Bladder pain syndrome/Interstitial cystitis, IIEF-5: International index of erectile function-5 score, PEDT: Premature ejaculation diagnostic tool, SD: Standard deviation 
the before BPS/IC-Group 1, it was 4.5 (1-18) in Group 2 $(p=0.955)$. Similarly no significant difference was found in terms of orgasmic function, sexual desire, intercourse satisfaction, and overall satisfaction scores between the before BPS/IC-Group 1 and Group 2 ( $p=0.825, p=0.803$, $p=0.939$ and $p=0.820$ respectively) (Table 3 ).

The median IIEF-5 scores were 23 (22-24) in both the after BPS/IC-Group 1 and Group 2 ( $p=0.899)$. Similarly, the median orgasmic function scores were 8 (7-9) in the after BPS/IC-Group 1 and Group $2(p=0.980)$ (Figure 1, Table
4). While the median PEDT score of men in the after BPS/ IC-Group 1 was 1.00 (4.00-12.25), the median PEDT score of the men in Group 2 was 4.50 (3.00-6.00) $(p=0.002)$. Similarly, the median sexual desire score was 7.00 (4.00-8.25) in men in the after BPS/IC-Group 1, and it was 8.00 (7.009.00) in the men in Group $2(p=0.003)$. While the median sexual satisfaction score was $8.00(5.00-11.25)$ in the after BPS/IC-Group 1, it was 12.00 (8.75-13.00) in Group $2(p=0.0001)$. The median of total satisfaction score was $6(3-8)$ in the after BPS/IC-Group 1, and it was 8 (6-9) in Group 2 ( $p=0.003$ ) (Figure 2, Table 4).

Table 3: Comparison of sexual functions before BPS/IC - Group 1 and Group 2

\begin{tabular}{lccc}
\hline Scores & Before BPS/IC-Group 1 & Group 2 & p value \\
IIEF-5, Med (min-max) & $23(9-25)$ & $23(8-25)$ & 0.750 \\
PEDT, Med (min-max) & $4(2-17)$ & $4.5(1-18)$ & 0.955 \\
Orgasmic function, Med (min-max) & $8(3-10)$ & $8(2-10)$ & 0.852 \\
Sexual desire, Med (min-max) & $8(2-10)$ & $8(2-10)$ & 0.803 \\
Intercourse satisfaction, Med (min-max) & $12(4-15)$ & $12(3-15)$ & 0.939 \\
Overall satisfaction, Med (min-max) & $8(3-9)$ & $8(2-10)$ & 0.820 \\
\hline
\end{tabular}

BPS/IC: Bladder pain syndrome/Interstitial cystitis, IIEF-5: International index of erectile function-5 score, PEDT: Premature ejaculation diagnostic tool, Med (min-max): Median (minimum-maximum)

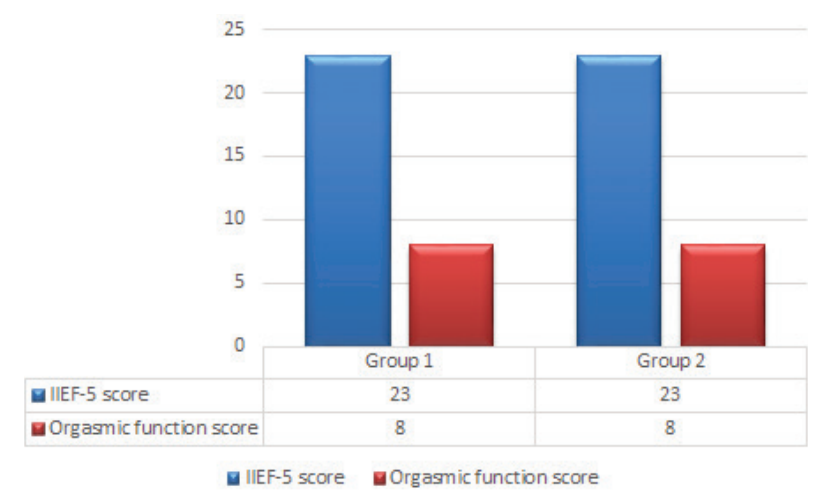

Figure 1: IIEF-5 and orgasmic function scores of the groups

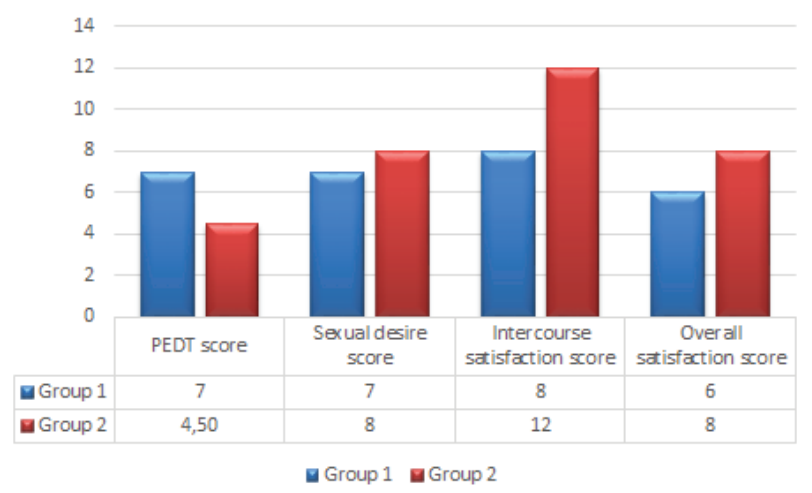

Figure 2: PEDT, sexual desire, intercourse satisfaction and overall satisfaction scores of the groups

Table 4: Comparison of sexual functions after BPS/IC - Group 1 and Group 2

\begin{tabular}{lccc}
\hline Scores & After BPS/IC-Group 1 & Group 2 & p value \\
IIEF-5,Median (IQR) & $23(22-24)$ & $23(22-24)$ & 0.899 \\
PEDT, Median (IQR) & $7.00(4.00-12.25)$ & $4.50(3.00-6.00)$ & $\mathbf{0 . 0 0 2}$ \\
Orgasmic function, Median (IQR) & $8(7-9)$ & $8(7-9)$ & 0.980 \\
Sexual desire, Median (IQR) & $7.00(4.00-8.25)$ & $8.00(7.00-9.00)$ & 0.003 \\
Intercourse satisfaction, Median (IQR) & $8.00(5.00-11.25)$ & $12.00(8.75-13.00)$ & $\mathbf{0 . 0 0 0 1}$ \\
Overall satisfaction, Median (IQR) & $6(3-8)$ & $8(6-9)$ & $\mathbf{0 . 0 0 3}$
\end{tabular}

IQR: Interquartile range, IIEF-5: International index of erectile function-5 score, PEDT: Premature ejaculation diagnostic tool 


\section{DISCUSSION}

Although, historically, male sexual health has been one of the primary areas of interest of urologists, recently women's sexual health has become one of the important research topics of urology (13). Although male and female sexual health is subject to examination separately, it is important to consider male and female factors together and to consider the partner effect when evaluating patients with sexual dysfunction (14). Recently, assorted studies reported the effect of the partner factor on sexual functions as a result of urological surgical procedures. These studies were conducted on the sexual functions of women and their partners especially after mid-urethral sling surgeries for female stress urinary incontinence (SUI). In studies conducted for this purpose, it indicated that the urinary incontinence in women also causes sexual dysfunction and improvement in sexual functions were achieved with successful incontinence surgery (15). Naumann et al. reported that a total of 73 patients applied for a single-incision mini-sling procedure and a success rate of $93.2 \%$ achieved (16). According to this study, the preoperative mean female sexual function index (FSFI) score of women was $23.86 \pm 5.67$, while the postoperative FSFI score was $27.25 \pm 4.66$ and significant improvement was observed in the postoperative period $(p<0.0001)$. Despite the reported high success rates of mid-urethral sling procedures in the treatment of SUI and the improvement in sexual functions provided by it, vaginal mesh exposure/extrusion reported at a rate of $6-6.5 \%$ in these procedures which may cause serious sexual dysfunction in both women and their male partners (17). In an editorial view emphasizing this issue, Braubaker stated that the partner dyspareunia (hispareunia), which can be seen after vaginal surgeries, often develops secondary to vaginal mesh extrusion (18). According to this view, it has been reported that the penile laceration and even bleeding can be seen in the male partner during sexual intercourse, and this situation negatively affects their sexual functions. These results support the idea that the female sexual dysfunction caused by physiological or psychosomatic factors also negatively affect the sexual functions of the male partner, as we emphasized in this study. Consistent with the literature, in the present study, it was determined that PEDT, sexual desire, intercourse satisfaction, and overall satisfaction scores deteriorated significantly in men with the development of BPS/IC symptoms in their wives in Group 1. Factors that negatively affect partner sexual functions may be related to pain or discomfort during sexual intercourse, which is defined as hisparonia, this situation can also develop secondary to the behavior of avoiding sexual intercourse due to vaginal/pelvic pain felt by the female partner before, during, or after intercourse without any pain or discomfort in the penis of the male partner $(19,20)$. McCabe et al. emphasized the effect of sexual avoidance behavior in the evaluation of male and female sexual dysfunctions and pointed out the necessity of evaluating the male and female partner together in the implementation of treatment modalities (21). Similarly, Carvalho et al. reported that sexual desire was directly related to the psychological state of the partners during sexual activity and that partner treatment should be considered together in sexual dysfunction (8).

Like the physiological and psychological factors, we have mentioned, it has been stated in different studies that the presence of BPS/IC has a negative effect on female sexual functions and the development of sexual avoidance behavior in these women. In the study performed by Peters et al., 5000 randomized women without IC and 407 women with IC, reported that the female sexual dysfunction and sexual distress developed at a significantly higher rate than in women with IC (22). In another study conducted by Yoon et al., it was reported that BPS/IC negatively affected the sexual life of women secondary to the increase in symptoms such as frequency, urgency, and vulvodynia (23). In another similar study, Ottem et al. reported that the rate of dyspareunia was $72 \%$ in the group of women with BPS/IC, while it was $5 \%$ in the control group without BPS/ IC $(p<0.0001)$ (24). In the same study, it emphasized that the mean FSFI score was $20.2 \pm 9.6$ in the IC/BPS group, while it was $29.9 \pm 6.3$ in the control group, and that IC/BPS negatively affected women's sexual functions $(p<0.0001)$. In another study conducted by Nickel et al. that included 128 patients with BPS/IC, it stated that the change in the mental and physical quality of life $(\mathrm{QOL})$ scores of the patients was correlated with the change in their sexual functions ( $r=0.46, p<0.0001$ and $r=0.29, p=0.0023$, respectively) (25). In a similar study, Bogart et al. reported that $75 \%$ of the 146,231 women with BPS/IC, who had sexual partners, of which $88 \%$ had $\geq 1$ general sexual dysfunction symptoms and $90 \%$ had $\geq 1$ BPS/IC specific symptoms within the last four weeks (26). In the same study they stated that the women with BPS/IC symptoms experienced very high levels of sexual dysfunction. In another study by Hung et al., 103 female patients with refractory BPS/IC were treated with intravesical hyaluronic acid $(\mathrm{HA})$ and the effect of that treatment on sexual functions as well as the improvement in symptoms were examined (27). According to the logistic regression analysis, they reported that a baseline Pelvic Organ Prolapse/Urinary Incontinence Sexual Function Questionnaire (PISQ-9) score was negatively correlated with the duration of IC/BPS symptoms $(p=0.022)$. At a result of their study intravesical HA may improve sexual function along with the reduction of IC/ BPS symptoms. In another similar study, Agrawal et al. compared thirty-two female patients with BPS/IC and thirty-two control group patients without symptoms (28). This study reported that the mean FSFI scores of women with BPS/IC were significantly worse than the normal group and BPS/IC caused sexual dysfunction $(18.678 \pm 4.531$ vs. $28.05 \pm 4.318 ; p<0.05)$. 
As stated in the aforementioned studies, BPS/IC emerges as an important factor causing sexual avoidance behavior and sexual dysfunction in women due to both the somatic pain it causes, and the depression and psychosomatic problems caused by the long-lasting discomfort. Like the literature data, in the present study, the men's sexual function scores whose wives did not have BPS/IC symptoms yet (Before BPS/IC-Group 1) was found to be similar compared to the normal population (Group 2). But it was observed that these men's PEDT, sexual desire, intercourse satisfaction, and overall satisfaction scores worsened significantly with the development of BPS/IC symptoms (After BPS/IC-Group 1) when compared to the normal population (Group 2). These results support the idea that the development of BPS/IC in women, as in other factors mentioned above, negatively affect the sexual functions of male partners. However, there are not enough studies investigating the effect of this disorder of women with $\mathrm{BPS} / \mathrm{IC}$ on the sexual functions of their male partners. According to the literature research conducted, this study is the first randomized study to evaluate this issue in detail. These results indicate that the sexual avoidance behavior is higher in women with BPS/IC and secondary to this, the frequency of sexual activity is decreased in these couples. In the present study, the higher frequency of premature ejaculation in the husbands of women with BPS/ IC compared to the control group may have developed secondary to the psychological stress caused by sexual avoidance behavior caused by dyspareunia or pelvic pain in women. Based on these results, it can be concluded that the dyspareunia and pelvic pain thatdevelop due to BPS/IC may cause various emotional and psychosomatic disorders in women, resulting in sexual dysfunction, and this situation leads to partner sexual dysfunction.

\section{Limitations}

The limited number of participants in this study is an important limitation. Additionally, the fact that sexual function was not questioned in female subjects, the relationship inventory was not included in the study, the sexual functions of women and their spouses were not examined according to BPS/IC phenotype subgroups and treatment responses can be considered as another limitation.

\section{CONCLUSION}

BPS/IC causes various degrees of sexual dysfunction in women. Especially dyspareunia and the emotional stress caused by it cause sexual avoidance behavior in women, which also leads to partner sexual dysfunction. Therefore, in the follow-up and treatment period of women with BPS/IC, the male partner sexual function should be evaluated in addition to female sexual function.

Informed Consent: Written consent was obtained from the participants.
Ethics Committee Approval: This study was approved by the Clinical Research Ethical Committee of the Kecioren Training and Research Hospital (Date:23.03.2021, No: 2012-KAEK-15/2274).

Peer Review: Externally peer-reviewed.

Author Contributions: Conception/Design of Study- K.S., Ç.Ş.; Data Acquisition- K.S., F.E.S., M.A.I., M.Ç.; Data Analysis/Interpretation- K.S., M.A.I., M.Ç.; Drafting Manuscript- K.S., M.A.I.; Critical Revision of Manuscript- Ç.Ş., Ö.F.B.; Approval and Accountability- K.S., Ç.Ş., M.A.I., F.E.S., M.Ç., Ö.F.B.

Conflict of Interest: Authors declared no conflict of interest

Financial Disclosure: Authors declared no financial support.

\section{REFERENCES}

1. Doggweiler R, Whitmore KE, Meijlink JM, Drake MJ, Frawley $\mathrm{H}$, Nordling J, et al. A standard for terminology in chronic pelvic pain syndromes: A report from the chronic pelvic pain working group of the international continence society. Neurourol Urodyn 2017;36(4):984-1008. [CrossRef]

2. Konkle KS, Berry SH, Elliott MN, Hilton L, Suttorp MJ, Clauw DJ, et al. Comparison of an interstitial cystitis/bladder pain syndrome clinical cohort with symptomatic community women from the RAND Interstitial Cystitis Epidemiology study. J Urol 2012;187(2):508-12. [CrossRef]

3. Colaco M, Evans R. Current guidelines in the management of interstitial cystitis. Transl Androl Urol 2015;4(6):677-83.

4. Forrest JB. Epidemiology and quality of life. J Reprod Med 2006;51(3):227-33.

5. Tripp DA, Nickel JC, Fitzgerald MP, Mayer R, Stechyson N, Hsieh A. Sexual functioning, catastrophizing, depression, and pain, as predictors of quality of life in women with interstitial cystitis/painful bladder syndrome. Urology 2009;73(5):987-92. [CrossRef]

6. Warren JW, Clauw DJ, Wesselmann U, Langenberg PW, Howard FM, Morozov V. Sexuality and reproductive risk factors for interstitial cystitis/painful bladder syndrome in women. Urology 2011;77(3):570-5. [CrossRef]

7. Gardella B, Porru D, Nappi RE, Dacco MD, Chiesa A, Spinillo A. Interstitial cystitis is associated with vulvodynia and sexual dysfunction-a case-control study. J Sex Med 2011;8(6):1726-34. [CrossRef]

8. Carvalho J, Nobre P. Gender issues and sexual desire: the role of emotional and relationship variables. J Sex Med 2010;7(7):2469-78. [CrossRef]

9. Furuya R, Masumori N, Furuya S, Oda T, Takahashi S, Takeuchi M. Glomerulation observed during transurethral resection of the prostate for patients with lower urinary tract symptoms suggestive of benign prostatic hyperplasia is a common finding but no predictor of clinical outcome. Urology 2007;70(5):922-6. [CrossRef]

10. Esen B, Obaid K, Süer E, Gökçe Mi, Gökmen D, Bedük $Y$, et al. Reliability and validity of Turkish versions of the interstitial cystitis symptom index and interstitial cystitis problem index. Neurourol Urodyn 2020;39(8):2338-43. [CrossRef] 
11. Akkus E, Kadioglu A, Esen A, Doran S, Ergen A, Anafarta K, et al. Turkish Erectile Dysfunction Prevalence Study Group: Prevalence and correlates of erectile dysfunction in Turkey: a population-based study. Eur Urol 2002;41(3):298-304. [CrossRef]

12. Serefoglu EC, Cimen HI, Ozdemir AT, Symonds T, Berktas M, Balbay MD. Turkish validation of the premature ejaculation diagnostic tool and its association with intravaginal ejaculatory latency time. Int J Impot Res 2009;21(2):139-44. [CrossRef]

13. McCabe MP, Sharlip ID, Atalla E, Balon R, Fisher AD, Laumann $E$, et al. Definitions of sexual dysfunctions in women and men: A consensus statement from the fourth international consultation on sexual medicine 2015. J Sex Med 2016;13(2):135-43. [CrossRef]

14. Yehuda R, Lehrner A, Rosenbaum TY. PTSD and sexual dysfunction in men and women. J Sex Med 2015;12(5):110719. [CrossRef]

15. Glass Clark SM, Huang $Q$, Sima AP, Siff LN. Effect of surgery for stress incontinence on female sexual function. Obstet Gynecol 2020;135(2):352-60. [CrossRef]

16. Naumann G, Steetskamp J, Meyer M, Laterza R, Skala C, Albrich $S$, et al. Changes in sexual function and quality of life after single-incision mid-urethral sling for treatment of female stress urinary incontinence. Eur J Obstet Gynecol Reprod Biol 2013;168(2):231-5. [CrossRef]

17. Stanford EJ, Paraiso MF. A comprehensive review of suburethral sling procedure complications. J Minim Invasive Gynecol 2008;15(2):132-45. [CrossRef]

18. Brubaker L. Editorial: partner dyspareunia (hispareunia). Int Urogynecol J Pelvic Floor Dysfunct 2006;17(4):311. [CrossRef]

19. Tarr M, Valaitis S. Tension-free vaginal tape vaginal erosion and penile abrasion. Female Pelvic Medicine \& Reconstructive Surg 2008;14(5):391-5. [CrossRef]
20. Mohr S, Kuhn P, Mueller MD, Kuhn A. Painful love"hispareunia" after sling erosion of the female partner. J Sex Med 2011;8(6):1740-6. [CrossRef]

21. McCabe M, Althof SE, Assalian P, Chevret-Measson M, Leiblum SR, Simonelli $C$, et al. Psychological and interpersonal dimensions of sexual function and dysfunction. J Sex Med 2010;7(2):327-36. [CrossRef]

22. Peters KM, Killinger KA, Carrico DJ, Ibrahim IA, Diokno AC, Graziottin A. Sexual function and sexual distress in women with interstitial cystitis: A case-control study. Urology 2007;70(3):543-7. [CrossRef]

23. Yoon HS, Yoon H. Correlations of interstitial cystitis/painful bladder syndrome with female sexual activity. Korean J Urol 2010;5(1):45-9. [CrossRef]

24. Ottem DP, Carr LK, Perks AE, Lee P, Teichman JM. Interstitial cystitis and female sexual dysfunction. Urology 2007;69(4):608-10. [CrossRef]

25. Nickel JC, Parsons CL, Forrest J, Kaufman D, Evans R, Chen $A$, et al. Improvement in sexual functioning in patients with interstitial cystitis/painful bladder syndrome. J Sex Med 2008;5(2):394-9. [CrossRef]

26. Bogart LM, Suttorp MJ, Elliott MN, Clemens JQ, Berry SH. Prevalence, and correlates of sexual dysfunction among women with bladder pain syndrome/interstitial cystitis. Urology 2011;77(3):576-80. [CrossRef]

27. Hung MJ, Su TH, Lin YH, Huang WC, Lin TY, Hsu CS, et al. Changes in sexual function of women with refractory interstitial cystitis/bladder pain syndrome after intravesical therapy with a hyaluronic acid solution. J Sex Med 2014;11(9):2256-63. [CrossRef]

28. Agrawal A, Tripathy S, Kumar D. Sexual dysfunction in women with interstitial cystitis/bladder pain syndrome: A case-control study. Indian J Urol 2020;36(3):212-5. [CrossRef] 